\title{
Periodization and modernity(ies) in international politics through R.B.J. Walker and Jens Bartelson
}

\author{
Periodização e Modernidade(s) na política \\ internacional via R.B.J. Walker e Jens Bartelson ${ }^{1}$
}

\author{
Paulo Henrique de Oliveira Chamon* \\ Victor Coutinho Lage**
}

\begin{abstract}
Critical investigations in the field of IR have connected its modes of problematization to a modern discourse on politics. In this paper, we propose to further these interrogations by investigating the role of the under-theorization of 'periodization' in reifying too narrow a concept of 'modernity' and, therefore, constraining available avenues for interrogating international politics. We proceed through a double problematization. First, we problematize the role played by periodization in the work of Jens Bartelson and Rob Walker, pointing to the pervasiveness-and yet silence over-this practice in two important moves to open space to think beyond modern political discourse. Second, we problematize periodization as a political practice that regulates past, present, and future, highlighting its double role in both reifying specific conceptions of history and the present, and in opening space for thinking about alternative timelines and modernities. We thus argue that periodization can have an important role in breaking through the temporal and historical boundaries limiting our understandings of international politics.
\end{abstract}

Keywords: international relations theory; modernity; periodization; Walker; Bartelson.

\section{Resumo}

Abordagens críticas de RI conectaram os modos de problematização do campo a um discurso político moderno. Neste artigo, propomos avançar tal argumento investigando o papel da subteorização do conceito de 'periodização' em fixar o significado da 'modernidade' em termos limitados, levando à redução das possíveis formas de interrogação da política internacional. Para tal, lançamos mão de duas problematizações. Primeiro, do papel da periodização nos trabalhos de Jens Bartelson e Rob Walker, apontando para a centralidade-e silêncio acerca-desta prática em dois dos mais importantes movimentos em prol de abrir espaço para pensar a política internacional além do discurso político moderno. Segundo, do conceito de periodização como uma prática política que regula passado, presente e futuro, ressaltando seu duplo papel de fixar determinados conceitos de história e do presente, assim como de abrir espaço para pensar modernidades alternativas. Assim, argumentamos que a periodização assume lugar central no questionamento das barreiras temporais e históricas que limitam formas de entendimento da política internacional.

Palavras-chave: teoria das relações internacionais; modernidade; periodização; Walker; Bartelson.

1 We would like to thank Philippe Bonditti, Rob Walker, Nick Onuf, and mainly Onofre dos Santos Filho and Stefano Guzzini for invaluable comments on previous versions of this text. We would also like to thank the anonymous reviewers of Carta Internacional for their valuable insights into our manuscript. We have presented a preliminary version of the text at the 2013 International Studies Association Annual Convention, held in San Francisco and at the 2015 Annual Meeting of the Associação Brasileira de Relações Internacionais, held in Belo Horizonte: we are thankful for the participants of both panels. We are also thankful for CAPES, CNPq, and FAPERJ for their support of the researches from which this paper stems.

* Doctoral Student at IRI/PUC-Rio and Assistant Professor at IRI/PUC-Rio.

** Assistant Professor at IRI/PUC-Rio and at CPDOC/FGV-Rio. 


\section{Introduction}

The field of International Relations witnessed, in the 1990s, a spur of exercises in historicization as an important part of the so-called "critical turn" of the discipline. More specifically, these historical readings have worked towards the characterization of 'modernity' and of the specifically 'modern' form of international politics as a way to criticize the reification of transhistorical categories². On the one hand, historicizations of 'modernity' were taken up by historical-sociological analyses looking to supply the incapacity of dominant structural approaches to account for the historical transformation from the "medieval (pre-modern) world" to the "modern state system"3. On the other hand, they also worked as a way to signify so-called contemporary transformations in modern politics towards new forms of organization of a "post-modern" world4.

While these arguments offered welcomed critiques to the intellectual and political poverty of many approaches, most of them have been criticized for reproducing a master narrative guided by Western experience and based on the presence/absence of the state and the state system. In this paper, we turn to two of such critics: R.B.J. Walker and Jens Bartelson, both of which have argued that many historicizations of modern international politics fail to acknowledge their own participation in a modern discourse that invites specific and pre-determined conceptions of transformation and epochal shift. Walker and Bartelson have showed that the under-theorized conception of 'modernity' underlying most interpretations of modern international politics poses problems to any attempt to think differently about politics given present conditions, as one tends to be caught affirming the very grounds one sets out to criticize.

However, the engagement in which we advance below, focused on two recent books written by Walker and Bartelson, exposes certain limits in their analyses that deserve further problematization. These limits signal towards implicit reifications and certain stalemates that impair their respective capacity to take us beyond the scope of alternatives already posited by modern political discourses.

Nonetheless, since all investigations must begin somewhere, the straightforward dismissal of any set of limits on ideological grounds is problematic. And yet, the proposition that an attempt to escape certain limits can ultimately reproduce those same limits works as an important indicative of the persistent need to interrogate the conditions under which one speaks. Hence, our objective in this paper will be to work through the contours of the discursive formation that leads those who are struggling to reconceptualize a given discourse towards the reproduction of this very discourse ${ }^{5}$. In this sense, we note that Walker's and Bartelson's reproductions of the very discourse they invite us to move away from shouldn't be taken as a slip that should be abandoned or easily corrected. On the contrary, taken seriously, these reproductions appear as symptoms of shared commitments to under-problematized features in their work and in the political discourse they work through.

\footnotetext{
2 One of the most concise statements of this kind can be found in Ruggie (1993).

3 For a direct engagement with structural realism on these terms, see, for example, Spruyt (1994), Buzan \& Little (1996); Reus-Smit (1999); and Philpott (2001).

4 Linklater $(1998 ; 2007)$ remains the main reference in this respect.

5 For more on this approach, see Foucault (1984; 1997), Butler (2002), and Bartelson (2001).
} 
In a similar vein, Hutchings has argued that "in spite of its commitment to challenging the international status quo, the temporal assumptions of critical theories tend to reproduce and confirm the hegemonic pattern of international power" (HUTCHINGS, 2007, p. 72), because although they "do much to undermine the role of the idea of progress in accounts of international political time, they are less successful in undermining the notion that a singular temporal perspective has a privileged status within international politics" (HUTCHINGS, 2007,p. 81)6. We will show that despite Walker's and Bartelson's successes in problematizing progressive accounts of international politics (among others), they find themselves reproducing a "singular temporal perspective" inscribed in the homogenization of "modernity". More specifically, we will argue that it is their commitment to non-problematized acts of periodization that sustain their implicit reification of modernity since they imply a naturalization of the distinction between past and present that homogenizes modernity, and, thus, stipulates very specific limits within which difference can be interrogated and imagined.

Indeed, as we will show, the concept of 'modernity' can hardly be separated from the acts of periodization that distinguish modern times from other, pre-modern, times (Osborne, 1992), thus making 'periodization', when understood as a political practice, a productive way of thinking through conceptions of 'modernity'. Consequently, the problematization of periodization we endeavor in this paper can work towards opening further space for interrogating and imagining alternative modernities.

We will do so through a double problematization. First, we problematize the role played by periodization in the works of Jens Bartelson and Rob Walker, thus pointing to the pervasiveness-and yet silence over-this practice in their arguments towards opening space to think beyond modern political discourse. Second, we problematize periodization as a political practice that regulates past, present, and future, highlighting its double role in both reifying specific conceptions of history and the present, and in opening space for thinking about alternative timelines and modernities. We thus argue that interrogating periodization can have an important role in breaking through the temporal and historical boundaries limiting our understandings of international politics.

\section{Questioning and silencing periodization in IR: R.B.J. Walker's and Jens Bartelson's problematization of international politics}

The concern with articulations of past, present and future marks most of Walker's texts; this is central, for instance, in his most cited and known work, Inside/Outside: international relations as political theory. ${ }^{7}$ There he explicitly states that "theories of international relations" can be read "as a crucial site in which attempts to think otherwise about political possibilities are constrained by categories and assumptions that contemporary political analysis is encouraged

6 Hutchings (2007) refers to the critique of the field of IR in the 1980 s by Ashley and Cox, and to arguments in both Virilio and Derrida. She turns to other analyses of world politics in her book (Hutchings, 2008). The problematization of international politics in Walker and Bartelson, however, isn't discussed.

7 We thank the anonymous reviewers for suggesting us to situate our discussion in relation to Walker's 1993 text. 
to take for granted" (WALKER, 1993, p. 5); or, more to the point, "a large proportion of research in the field of international relations... simply [takes] a modernist framing of all spatiotemporal options as an unquestionable given" (WALKER, 1993, p. 7).

The explicit focus that Inside/Outside gives to international relations leads Walker to "treat the primacy of space in cultural and intellectual experience of the early modern era as crucial, as setting the conditions under which later accounts of temporality... could be articulated as a linear and thus measurable progression" (WALKER, 1993, p. 11). Taking that into account, his main concern in the text is to understand how the commitment to the principle of state sovereignty "tells us more about the constitutive imagination of modern political life than about the determinations and possibilities of the political worlds in which we now live" (WALKER, 1993, p. 25, emphasis in the original). In other words, Walker provides us with theoretical reflections to pursue the interrogation of the "spatiotemporal" articulations that have come to constitute the ways through which we interpret modernity.

Our effort here builds from this kind of reflection. In this paper, however, we focus on his more recent book, After the Globe, Before the World, since it articulates, in our view, a more complex problematization of "the international" -the central notion in our interpretation of the periodization practices at stake in his thought-in relation to his earlier intervention. We argue that, in this text, Walker himself reproduces, to paraphrase his own earlier words, "categories and assumptions that contemporary political analysis is encouraged to take for granted"; more precisely, we argue that he relies on a periodization that, paraphrasing again, "constrains political possibilities" and that is telling of "the constitutive imagination" of "modern political life". To make that point, we now move more closely to the text. (referência)

In the beginning of the book, Walker states that his

overall argument, to put it briefly, is that anyone seeking to reimagine the possibilities of political life under contemporary conditions would be wise to resist ambitions expressed as a move from politics of the international to a politics of the world, and to pay far greater attention to what goes on at the boundaries, borders and limits of a politics orchestrated within the international that simultaneously imagines the possibility and impossibility of a move across the boundaries, borders and limits distinguishing itself from some world beyond (WALKER, 2010, p. 2-3, emphasis in the original).

The book is especially devoted to problematize the claims that put "the international" and "the world" either as antonyms or as synonyms. On the one hand, to treat them as synonyms is, according to Walker, a particular invitation to discourses of universality and universalization, claiming for a shift from the local, the parochial, the national to something more enlightened and cosmopolitan. That is, to put them as synonyms leads to linear perspectives that either affirm the universal condition of modernity or assume that, within historical development, this universal condition must be attained. What underlies this conception is the move from the particular to the universal. On the other hand, to treat them as antonyms is to affirm the impossibility of political life beyond the boundaries of the modern state. Instead of unity, this view expresses the fragmentation of the coexistence of particular modern states, within which lies exclusively the possibilities of freedom and politics. 
This either/or logic would be the reproduction of "the logic of affirmation and negation enabled at the edge of the modern system of sovereign states that claims to be, but never can be, coextensive with the world" (WALKER, 2010, p. 22). To avoid this blackmail, Walker claims that "the international" and "the world" must be read as both antonyms and synonyms; from this interpretation,

the relation between an international politics and a world politics affirms both the ambitions and limits-the possibility and impossibility-of specifically modern forms of politics: forms of politics that aspire to be universal, to engage the entire world, yet must always eventually acknowledge, tacitly or explicitly, that the entire world is forever beyond reach (WALKER, 2010, p. 22).

In a certain sense, Walker's effort is devoted to replace this both/and logic for the either/ or logic mentioned above. More precisely, his main target is to problematize the notion of "the international", without reproducing the logics that keep the particular and the universal in a dualist perspective, from which one pole is privileged, in detriment of its opposite. Following that reasoning, the particular and the universal become, to Walker, expressions of inherent and insoluble contradictions that constitute modern political life.

Here, we propose that Walker's text can be read as an attempt to problematize the periodization acts involved in the either/or logic explained above, a logic that is imbued with assumptions regarding specific arrangements of past, present and future.

According to this proposition, we can articulate the problematization of After the Globe, Before the World exposed above in the following terms. On the one hand, the conception of "the international" and "the world" as synonyms implies three interrelated claims. First, it presumes a pre-modern (feudal) past which is different from the present (international) modern condition. Second, this present modern condition is taken either as an already universal condition or as a condition in the historical process of universalizing itself. Finally, third, this future is posited as the unfolding of the founding principles said to demarcate modernity from pre-modernity.

On the other hand, the conception of "the international" and "the world" as antonyms also implies three interrelated claims. First, as before, it presumes a pre-modern (feudal) past which is different from the present (international) modern condition. Second, however, the modern state is posited as the exclusive condition of political life. Finally, third, the future of the international becomes submitted to the law of repetition given the impossibility of political life beyond the modern state for modern subjectivities.

That said, what remains to be seen is how Walker deals with his own acts of periodization. More precisely, we argue, Walker himself relies on certain periodizations that are largely ignored, but that have crucial political implications to think contemporary politics. The first thing to be noticed in this aspect, then, is his conception of modernity. If, on the one hand, Walker provides us with a powerful reading of what is at stake in contemporary claims on "modernity" and "modern politics", and their implications in the various instances of their use, on the other hand, his own conception of modernity seems ambiguous and under-theorized. 
An indication of how his conception of modernity remains under-theorized is that the instance in which his most explicit definition of modernity is provided comes only at an (end) note to the second chapter. There, one reads:

my identification of modernity with the emergence of the states system in early-modern Europe is intended both as a shorthand reminder of the parochialisms embedded in many more familiar accounts of what modernity must be, and a suggestion that the inclusions/ exclusions expressed in the European states system, with its own constitutive exclusions, provide a neglected dimension of debates about modernity that, partly as a consequence, remain either resolutely Eurocentric or determined to resist European/Western hegemony, with both options encouraging essentializing accounts of modernity and its others (WALKER, 2010, p. 262, n.6).

Here, modernity is identified with the states system that has supposedly emerged in "early-modern Europe", in order to highlight "parochialisms" and "essentializations" in other definitions of modernity.

Elsewhere, he says that "modern politics has come to be, among other things, an international politics" (WALKER, 2010, p. 47). If, above, modernity is identified with the states system of early-modern Europe, now it is directly identified with "international politics". But, Walker highlights that many of the features of modern politics "pre-date the kind of structural formations we now call the international" (WALKER, 2010, p. 47) He starts the (end)note at the end of this quotation by saying that, "read as history", what is called "the international came to be named (by Jeremy Bentham) only in the very late eighteenth century. It may make sense to use it as an explanatory category only since the nineteenth century" (WALKER, 2010, p. 274, n.41). Opposed to these historical readings, Walker identifies structuralist readings, through which "the international is invariably traced back much further, to the mid-seventeenth century at least, and even to various pre-modern formations: thus Thucydides" (WALKER, 2010, p. 274, n.41). Before these two definitions, Walker highlights that the structuralist ones, despite being less historically accurate, are right in insisting that the modern state emerged only under external conditions of possibility. In other words, structuralist readings would be misleading in identifying a figure like Thucydides as a thinker of "the international", since he is part of "pre-modern formations", but would be accurate, logically speaking, to the extent that they shed light on how the "inside" of the modern state has the "outside" as its conditions of possibility. In these two (end)notes of chapter two, Walker traces lines that separate "modern politics" and "modernity" from "pre-modern formations" and from what came "before the international".

In that sense, Walker's problematization of modernity and modern politics through a both/and logic has as its own condition of possibility a specific definition of modernity. That is, in order to criticize the assumptions at stake in interpretations of "the international" and "the world" as either antonyms or synonyms, Walker constructs a definition of modernity that relies on a periodization ultimately taken for granted: the early-modern system of states from which modern politics is equated with international politics and differentiated from premodern formations. It would thus seem that his critique of modern politics and modernity, while 
highlighting the contradictions between the universal and the particular, assumes one specific form of these contradictions, naming it "international" or "modern" politics. Therefore, we argue that Walker's both/and logic relies in a definition of what modernity actually means that leads to a (re)instantiation of an either/or logic: modern contradictions are either present or absent in one's interpretation, depending if the interpreter grasps, in an appropriate way, the specifically modern configurations of the problem of political community that Walker identifies in history.

A similar reading of the double role of periodization can be made of Jens Bartelson's Visions of World Community, which deals with issues of universality and particularity similar to those found in our discussion of R.B.J. Walker. Most notably, Bartelson's argument differentiates itself from Walker's due to the centrality that historical investigation assumes in it. This difference will be at the center of our analysis, as it speaks directly to matters of periodization.

Indeed, the author explicitly draws on history and periodization in order to make his argument about the possibilities and impossibilities of a world community, according to which

our present inability to make coherent sense of the idea of world community is the outcome of a successful nationalization of the concept of community itself, a process through which the nation became the paradigmatic form of human association in theory and practice alike (BARTELSON, 2009, p. 4, emphasis in the original).

According to Bartelson, through this process of nationalization, we lost the capacity to think about "a more encompassing social whole, of which both communities and individual human beings could form part" (BARTELSON, 2009, p. 35, emphasis added). That is, we have lost a universalist social ontology as the basis upon which our conception of political community is conceived, replacing it with a particularistic social ontology revolving around the bounded nature of all community.

It should be noted that, in The Critique of the State, Bartelson (2001) had pointed out that the state concept "in its modern sense" "became fused with the concept of the nation, thus establishing a firm logical and rhetorical connection between political authority and political community" (BARTELSON, 2001, p. 35). Moreover, the "historical understanding of the state and the state-centric understanding of history are closely related to another major change in the structure of sociopolitical concepts: the fusion of the concepts of state and nation" (BARTELSON, 2001, pp. 38-9). In sum, Bartelson (2001) is devoted to the problematization of what he identifies as a specifically "modern" configuration of authority and community. ${ }^{8}$.

In The Critique of the State, Bartelson's concern with the state concept leads him to "analyse how [it] came to fulfill a constitutive function within late modern scientific political discourse - that is, beyond [Max] Weber - and how this concept subsequently became an unquestioned part of political reflection" (BARTELSON, 2001, p. 9). In Visions of World Community, in turn, he aims at exploring "some of the changes the concept [of community] has undergone as a result" of past centuries contestation and recycling "within political thought" (BARTELSON, 2009, p. 10).

8 Here as well, we thank the anonymous reviewers for suggesting the inclusion of the reference to Bartelson's 2001 book. 
In relation to his 2001 book, Bartelson took a step back in history in his 2009 book, in order to understand how the logic of identity underlying the state concept in its modern sense came into being through a certain historical process. One of the results of that historical process is a well-known challenge of international politics: while the modern political community is instantiated within the limits of the bounded nation-state, many of the problems that these societies face (e.g.: environmental sustainability, transnational justice) have a boundless nature. Bartelson goes on to argue that, facing such challenges, and without being able to resort to a lost universalist ontology, many political theorists have attempted to conceptualize the expansion of the political community into an instance capable of dealing with boundless problems. However, such moves face strong limitations given that

the very same division of mankind into distinct communities that makes the idea of a world community morally compelling has also been the main obstacle to its successful realization, since differences between peoples have made such a community hard to attain in practice. Consequently, many of those who have defended the idea of world community have done so by arguing that the world of sovereign states first has to be transcended in order to make way for a coming community of all mankind (BARTELSON, 2009, p. 1).

Bartelson's crucial move is thus to relate the different discourses on cosmopolitanism to a common ontological assumption: a particularistic conception of community that constructs the world as necessarily consisting of a plurality of bounded communities. According to the author, the problem with such ontology is that it locates particularity and universality in opposition to each other; Consequently, as "[t]here is simply no corresponding conception of world community to match the universalistic aspirations of cosmopolitan democrats-just an ontological void in between communities" (BARTELSON, 2009, p. 28), the boundaries of the nation-state set the limits of all modern political analyses, thus calling for transcendence if any form of world community is to be imagined. Given such either/or approach, attempts to deal with the aforementioned challenge cannot escape resulting into a paradox that must presuppose the prior existence of the very "broader" community it is supposed to justify into existence (see BARTELSON, 2009, ch.2).

As with Walker, we argue that Bartelson can be read as problematizing the specific periodization that informs cosmopolitan approaches to world politics. In such interpretation, Bartelson's argument exposes how these thinkers operate a specific organization of past, present, and future that makes a world community the desirable future that is always already contained within present (modern) forms of politics expressed in the sovereign state. These forms, furthermore, imply a previous distinction between a pre-modern political organization whose principles are unsuitable to modern subjectivity-thus justifying the need to go "forward", not "backward". Hence, modern politics calls forth a will to transcend itself towards a world community-a future that is already implied in the definition of a modern world of sovereign states that is distinct from a pre-modern one.

We argue that Bartelson's own diagnosis of the paradoxes of cosmopolitan approaches to world community relies upon an act of periodization that (re)produces the very dynamics he intends to dissolve through his analysis. Indeed, the historical process of nationalization of the 
political community is depicted through a historical narrative revolving around two major explicit breaks. The first one is associated with the Copernican Revolution and changes in cartography, both of which set the conditions for the establishment of a vantage point above the Earth from which a world community could be envisioned (BARTELSON, 2009, p. 72ff). Such Renaissance redrawing of world community sets the stage for what Bartelson presents as two centuries of debate between nationalizing tendencies-attempting to locate the vantage point of community within the state system itself-against a backdrop of universalized visions of world community-founded upon cosmological beliefs on human beings innate sociability, progressive history or Humanity. According to Bartelson, this struggle is put to an end when nineteenth century romantics, the epitome of which is expressed in Hegel and the French Revolution, managed to ultimately nationalize all conceptions of community, making it impossible to envision world community in others terms than through a particularistic ontology. In his words,

[t]he route from this point to our present difficulties in making coherent sense of the idea of world community is surprisingly short. When mankind had been subdivided along so many dimensions, and when the nation-state had been reified into an inescapable fact of human life, the only remaining way of formulating the problem of world community was in terms of the insurmountable difficulties involved in transcending all these divisions simultaneously. What had been an indispensable part of the background understanding of political reflection from the Middle Ages to the Enlightenment had now finally been relegated to the status of an unattainable utopia (BARTELSON, 2009, p. 170).

Just as the Copernican Revolution opened the ground for attempts to particularize an a priori universal community, the French Revolution ultimately expressed a shift in the poles of the debate, rearticulating it in terms of attempts to universalize a priori particular communities. To Bartelson, from this moment on, the possibilities of thinking about world community in terms other than those established by ontological particularism have become no more than variations of an "unattainable utopia"; in other words, the oppositional relation of either universal or particular was substituted for an understanding of political community as both universal and particular. In this sense, while Walker's both/and logic is an analytical way proposed to shed light upon the tensions between particularity and universality in "the international", Bartelson's both/and understanding of the mutual implication of universalistic and particularistic conceptions of community is situated as a historical trend in political thought that was dominant for centuries and that has, at some point in time, a date of birth and a date when it was displaced from its dominant position.

Hence, his either/or and both/and logics are founded upon an a priori either/or frame historically situated through periodization: either universality and particularity are mutually implicated or they are in opposition, depending on the social ontology of the period in which it is situated. Such articulation of an historical narrative of world community ends up sealing the meaning of modernity in a very specific way, leading Bartelson to reproduce the need for transcendence he sets out to problematize. Here, however, the transcendence would refer to the overcoming of the particularistic social ontology underlying the system of sovereign states. Slightly rephrasing Bartelson, we could say that, since there is "just an ontological 
void in between [social ontologies]", the boundaries of each era, expressed in the narrative periodization, set the limits of Bartelson's political analysis, thus calling for transcendence if any form of world community is to be imagined.

Our interpretation of Walker's and Bartelson's arguments highlights how they rely on a periodization between modernity and pre-modernity in order to establish their problematization of the relation between the international and the world. In doing so, they also implicitly fix a specific meaning of modernity in ways that foreclose dissent and invite an underlying either/or approach. ${ }^{9}$ That being said, our effort in this text moves along lines of problematization that Walker and Bartelson themselves have tackled in the field of "international relations". However, as we have showed, their texts ultimately rely in different ways on certain modern/pre-modern divides that remain silenced. It is this silence on periodization itself that we want to address and explore.

\section{Problematizing periodization}

This presentation of the arguments of R.B.J. Walker and Jens Bartelson calls for closer attention to the practice of periodization. Indeed, as argued, while both can be read as questioning the underlying periodization in other thinkers in IR, they remain themselves silent about their own, thus erasing the foundational move that authorizes their arguments. In this section, we propose to shed light upon the stakes of such practice and, therefore, open space for further advancing the problematization of international politics towards alternative modernities.

It is not our claim that periodization "in itself" should be condemned, avoided or superseded. Rather, we insist that periodization should not be seen as a description of "the" past; rather, it is a political device that works towards producing identities and differences. Taking that into account, the modern/pre-modern divide cannot be taken as a description of historical periods, but as a specific way of organizing political discourse. To frame it differently, problematizing periodization, as we understand it, does not require its eradication; it is, instead, a call for a persistent critique of the political implications in any periodizing act. This section is devoted to unfold that proposition.

We begin with Michel Foucault's reflections on The Order of Things. This is a valuable entry point for us, as it is not only a book wholly structured around periodization, but also one that explicitly discusses the centrality of historical discontinuities all the while opting for silencing their consequences. Hence, it is particularly careful not only about the stakes of following his methods, but also about the need for a given set of silences in order to do so.

Foucault claims that

[e]stablishing discontinuities is not an easy task even for history in general. And it is certainly even less so for the history of thought. We may wish to draw a dividing-line; but any limit we set may perhaps be no more than an arbitrary division made in a constantly mobile whole. We may wish to mark off a period; but have we the right to establish symmetrical breaks at

9 Such foreclosing of possibilities for thinking otherwise is an important element of the debate between Walker and Bartelson itself, where one has endeavored to point the limits that the other's approach presents to political difference. For some instances of their direct engagement, see Bartelson (2001, pp. 167), Bartelson (2011), and Walker (2011). 
two points in time in order to give an appearance of continuity and unity to the system we place between them? Where, in that case, would the cause of its existence lie? Or that of its subsequent disappearance and fall? What rule could it be obeying by both its existence and its disappearance? If it contains a principle of coherence within itself, whence could come the foreign element capable of rebutting it? How can a thought melt away before anything other than itself? Generally speaking, what does it mean, no longer being able to think a certain thought? Or to introduce a new thought? (FOUCAULT, 2002, p. 55-6).

Foucault, however, in a move similar to those presented in the previous section, decided to silence these questions in The Order of Things ${ }^{10}$, moving on with his analysis of Western thought through historical discontinuities. Walker and Bartelson both seem to implicitly follow him in such silence. We nonetheless propose to take these reflections up as a point of entry into the problematization of periodization. Indeed, they highlight not only the arbitrariness of historical breaks, but also their implications: the need to rely on something outside themselves to exist, the creation of an illusion of coherence and unity, the disavowing of the past. In other words, questions of periodization cannot be dissociated from questions of discrimination and demarcation.

We argue that the act of periodization, when naturalized as either natural or simply heuristic, implicates the production of what Richard Ashley called, in another context, a "deep structure", that is, "an autonomous code, a fixed generative principle" that disciplines meaning and fixes contingencies, giving an appearance of coherence and stability (ASHLEY, 1988, p. 232). In other words, in creating straight boundaries in history, periodization allows for the production of periods as coherent entities that can be clearly differentiated from other such coherent entities. Periodization thus works as an act of grounding that often leads to fixing and naturalizing the play of identity and difference, contingency and necessity, coherency and incoherency. In the terms of this article, this means that the non-problematization of the periodization between pre-modernity and modernity tend to produce both periods as coherent and homogeneous entities, following clearly defined generative principles. As Nicholas Onuf reminds us, telling a story about "modernity" involves mobilizing metaphors such as "boundary", "break", "juncture", "limit", "rupture", "stage", "transition"; and to speak about history does not mean that "history-that thing called history-is going anywhere in particular" (ONUF, forthcoming, emphasis in the original).

However, this agreement results in blackmail: one must either accept or reject the presented coherent discourse; any given present must either be modern or not modern. Acceptation or repudiation of the deep structure are the only available alternatives. As both options revolve around the presence or absence of the same discursive sovereign center, that is, of a delimited (because periodized) concept of modernity, the array of possibilities available for imagining and interrogating difference towards alternative modernities is considerably limited. To periodize, in this sense, becomes not a neutral, epistemological or hermeneutical matter of giving names to, or unveiling, what is already present in history itself, but a political technique

10 After explicating such limits, Foucault (2002, p. 56) states: "perhaps it is not yet time to pose this problem; perhaps we should wait until the archaeology of thought has been established more firmly (...) before attempting to encompass thought and to investigate how it contrives to escape itself". 
that constitutes the very grounds of history, their internal and external limits, and regulates past, present, and future.

In a similar way, Kathleen Davis argues that periodization "does not refer to a mere backdescription that divides history into segments, but to a fundamental political technique-a way to moderate, divide, and regulate-always rendering its services now. In an important sense, we cannot periodize the past" (DAVIS, 2008, p. 5). This notion contrasts with what she sees as the practice of periodization as an effacement of politics. Such conceptualization leads her to look into the break that allegedly separates the "medieval", the "sacred", the "feudal" from the "modern", the "secular", the "capitalist" as an operation intrinsically connected to particular conceptions of sovereign state and secular politics. The reproduction of the medieval/ modern periodization is not an empirical claim to history, but a philosophical and political problematization: "modernity" works as the historical period in which the modern state has freed itself from the ecclesiastical authorities and that capitalism developed out of feudal relations; at the same time, this historical period is exactly what constructs, hierarchically, that from which it has historically freed itself (DAVIS, 2008).

This move is also stressed by Constantin Fasolt, according to whom "[modern political thought] presupposed ideas like 'politics' and 'the state' that were only the result of the development under investigation" (FASOLT, 2004, p. 219), incurring in a proleptic move that privileged "modernity" against "Middle Ages". The "Modern world" is political by nature, precisely in its being historical; its reality derives from a subject's projection, not from its quality of being so "in itself". A particular conception of the state and a particular conception of the subject are both built into the limits of history ${ }^{11}$ and, hence, in the articulation between history and politics, between "modernity" and "its others". It is impossible to step outside history to grasp the past as a metaphysical origin; history already presupposes an origin without which it is impossible, but with which it is not purely historical, but also political (FASOLT, 2004).

Fasolt and Davis agree that the main problem with periodization derives from its affirmation of the belief that one of the main roles of history should be about producing knowledge of the past, thereby effacing the presuppositions of this practice. Such problematization of the political implications of periodization can be said to be inscribed in every performative act that aims at tracing lines at once between a "before" and an "after" and between "us" and "them", being constitutive of the most pervasive acts of periodization that are constantly reenacted and/or presupposed in daily and academic discourses. Furthermore, they both highlight how the modern/pre-modern divide is directly related to some of our deepest commitments such as freedom, the state, citizenship, and history.

To sum up, we argue that these reflections call into attention how periodization is never just a description of a past in itself, but always also a political move that works towards producing identities and differences. Hence, the modern/medieval-or modern/pre-moderndivide cannot be taken for granted as representing distinct periods in history.

11 According to Fasolt, "[i]f history is the form in which we contemplate a past that is immutably divided from the present, then citizenship, sovereignty, and the state are the categories by which we declare our freedom to change the present into the form that we desire for the future". (FASOLT, 2004, p. 7). 


\section{Performing the limits of history}

We have thus far shown that the modern/pre-modern divide works as a political device that fixes a specific meaning of modernity. In taming meanings within one singular timeline, the modern/pre-modern divide, pervasive even in critical endeavors such as the ones studied above, bears the signs of a Eurocentric conception of world politics ${ }^{12}$.

One endeavor to challenge such singular temporalities speaks to our work in its questioning of the stability of the nation. Bhabha (1994) has argued that the nation must always be both the object of a historical pedagogy that affirms its authority in the past through historical continuity and origins, and the subject of a performative process in which its contemporaneous identity with itself is reaffirmed in the present. In other words, the nation must be both a singular temporal perspective stretching continuously back in history to distant origins and a constant work of (re)production of its homogeneity.

The temporal repetition of the performative temporality of the nation both feeds and undoes the pedagogical timeline of nationalism in a supplementary logic that exposes the heterogeneous temporalities of the Nation-State ${ }^{13}$. It would be unfair to both Walker and Bartelson to compare their problematization of international politics to the kind of nationalism being challenged by Bhabha. Nonetheless, in the latter's insight into the performative work that goes into the formation (and deformation) of singular timelines, we see possibilities for interpreting periodization as a (de)stabilizing procedure-and thus problematizing its work.

Maybe the most comprehensive attempt to question singular temporal perspectives on world politics has been Hutchings' investigation of the temporal assumptions of discourses about world politics. According to her, a wide range of readings of world politics are inadequate for two reasons:

[i]n the first place, they are inadequate because, whether critical or not of western modernity, they are profoundly blinkered by their attachment to the idea that we can use western modernity as the key to making sense of the past, present, and future of the world as such. In the second place, they are unsatisfactory because they put the theorist in the positions of time-traveller and prophet, thus succumbing to (...) the temptation of thinking that politics is conditioned by the possibility of making or controlling time (HUTCHINGS, 2008, p. 160).

Two problems sum up Hutchings's critique: the unification of the present-the idea that there is one present, coming from one traceable past-and the timeliness of critique-the idea that one writes for one's time (even if by being somehow displaced from one's time ${ }^{14}$ ). While the assumption of timeliness is certainly present in both texts analyzed above, we want to highlight the first point, that is, how the acts of periodization that sustain their arguments cannot be

\footnotetext{
12 For specific readings of the Eurocentrism of the field IR, see Hobson (2012), Muppidi (2012), and Jones (2006); for IPE, see Inayatullah \& Blaney (2004), Blaney \& Inayatullah (2010), and Contexto Internacional's special issue on IPE as global conversation (2015).

13 "The way other temporalities live alongside the temporalities of the Nation is also explored by Shapiro (2000; forthcoming) and Chatterjee (2004).

14 See Agamben (2009).
} 
dissociated from the production of a unified present. According to Hutchings, to think against these assumptions is to take up "the challenge of thinking heterotemporality, ultimately neither one present nor many presents, but a mutual contaminations of 'nows' that participate in a variety of temporal trajectories and which do not derive their significance from one meta-narrative about how they all fit together" (HUTCHINGS, 2008, p. 166).

In order to think such heterotemporality we turn to how Dipesh Chakrabarty's critique of Eurocentrism through the doubling of history can help displace singular temporal perspectives not only in terms of the Nation, the nation-state, or the event, but of historical perspectives in general15.

Chakrabarty distinguishes two different modalities of history. In his terms, History 1 is "the backbone of the usual narratives of transition", "a past posited by capital itself as its precondition" and that "lends itself to the reproduction of capitalist relationships". We could say that when History is reduced to History 1, we get what Chakrabarty calls "historicism", the mode of thinking that "made modernity or capitalism look not simply global but rather as something that became global over time, by originating in one place (Europe) and then spreading outside it" (CHAKRABARTY, 2000, p. 7, emphasis in the original). For the author, historicism is a "transition narrative", often expressed in terms of "development", "modernization", and "capitalism"; and in terms of "absences", "failures", and "incompleteness" (CHAKRABARTY, 2000, p. 30-4). In this sense, what Chakrabarty calls "historicism" is directly connected to the practice of periodization and to the modern/pre-modern divide as they have been presented in this paper. They both operate as narrative homogenizations of differences under a unified historical movement.

What is of interest to us is how Chakrabarty locates within historicism-and, for our purposes, how we locate in periodization-the possibility of its own interruption and displacement in terms of other narratives. In this sense, History 2 marks all those pasts, presents, and futures that exist in excess to those considered necessary by History 1 for its own constitution and reproduction (CHAKRABARTY, 2000, p. 63-4).

Chakrabarty "then narrates historical complexity not as a reversal of polarity between a "universal History" and "particular histories", but as the encounter between a history made universal and the elements integral to, but also in excess of, this history. In Chakrabarty's terms: "History 2 do not constitute a dialectical Other of the necessary logic of History 1 (...). History 2 is better thought of as a category charged with the function of constantly interrupting the totalizing thrusts of History 1 (CHAKRABARTY, 2000 , p. 66, emphasis added). To remain with his terms, this "disjuncture" does not mark a mutual exclusion between "subaltern pasts" (History 2) and "historicization" (History 1): "[i]t is because we already have experiences of that which makes the present noncontemporaneous with itself that we can actually historicize" (CHAKRABARTY, 2000, p. 112 ).

Therefore, on the one hand, these interruptions feed the so-called "totalizing thrusts" of History 1, that is, the constant work of heterogeneity of History 2 invites the totalizing activity of

\footnotetext{
15 Chakrabarty's argument can be located within a broader set of claims reclaiming times and spaces that colonialism, imperialism, and Eurocentrism have obliterated. For an interpretation of the field of limits and possibilities that emerges through and between these claims, see Chamon \& Lage (forthcoming). For a different interpretation of the role of 'interruptions' between History 1 and History 2 that engages critically with Chakrabarty, see Blaney \& Inayatullah (2010, ch.6).
} 
transition narratives. On the other hand, however, as these experiences of noncontemporaneous presents are not tied, in any necessary way, to a historicized perspective, the possibility for alternative interpretations is opened up.

In this sense, "[a]n appreciation of this problem ['historicism] has led to a series of attempts to craft histories differently, to allow for a certain measure of equality between 'historians' histories and other constructions of the past"; by doing this, he claims, one "perform[s] the limits of history" (CHAKRABARTY, 2000 , p. 106, emphasis in the original). Thus, instead of a vocabulary marked by "lack", "incompleteness", and "not yet", by "before", "after", and "pre/ post", it is possible to explore the forces constitutive of what Chakrabarty calls "the ontological "now'" (CHAKRABARTY, 2008, p. 113)16. In this sense, "minorities histories" can raise problems to the homogenization of difference under a historicized perspective, since they "must implicitly assume a plurality of times existing together, a disjuncture of the present with itself" (CHAKRABARTY, 2000, p. 109).

\section{Final remarks}

We read Chakrabarty's heterotemporalities as an invitation to rework through the singular temporal perspective that the modern/pre-modern divide fixes as the ground for the problematization of international politics in Walker and Bartelson. In the terms of this paper, thus, we argue that this divide limits the array of possible interpretations because Walker's and Bartelson's constitutive silence on their own acts of periodization reifies homogeneous historical periods as an ontological dimension of political life instead of a specific framing of the relation between identity and difference in time.

However, by following Chakrabarty reading of historicism, what emerges is the possibility of substituting the exploration of the heterogeneities constituting the "ontological now" for the double status (as a condition of political knowledge and as its fundamental object) of the modern/pre-modern divide. As heterogeneity is both always already present as a condition of possibility of periodization and tamed through acts of periodization, we might sidestep the blackmail of maintaining or discarding historian's history, and begin moving towards the multiplicity of narratives that can be woven through different performances of both. The prospect, we believe, is much more productive than Fasolt's fatalist disappearance of historians as the ultimate condition for the transformation of history and politics.

In this sense, we once more highlight that, in calling attention to the political workings of taken-for-granted divides imposed upon "history itself"-and, more precisely, to the divide between modernity and pre-modernity inscribed in the texts presented above-we do not claim that periodization should be overcome or transcended towards a different, supposedly "purer" or "more authentic", experience of the passage of time. Instead, we want to address the field of possibilities that is opened by a more nuanced interpretation of history. In this sense, we invite less a post-periodization theoretical approach (which appears to us, at best, as a diagnostic

16 For a somewhat different perspective calling for the same kind of work, see Shilliam (2011). 
paradox ${ }^{17}$ ) than a disposition to read periodization as a site of questioning, interrogation and interrupting from which political problems can emerge.

There is much to be done following this path, we believe. We find support in this assertion in recent works within the field of International Relations that have endeavored to problematize the ways in which specific conceptions of temporality, history, and "the present" are naturalized in our understanding of international and world politics. In arguing for the systematic problematization of the workings of periodization in IR theory, particularly in the works of Walker and Bartelson, we hope to point to periodization as an important dimension to be explored and thus join our voices to those working towards breaking through the temporal and historical boundaries that limit our political imagination.

\section{References}

AGAMBEN, Giorgio. What is the contemporary? In: AGAMBEN, Giorgio. What is an apparatus? And other essays. Stanford: Stanford University Press, 2009, p. 39-54.

ASHLEY, Richard. Untying the Sovereign States: double readings of the anarchy problematique. Millennium: Journal of International Studies. v. 17, n. 2, 1988, p. 227-262.

BARTELSON, Jens. The Critique of the State. Cambridge: Cambridge University Press. 2001

BARTELSON, Jens. Visions of World Community. Cambridge: Cambridge University. 2009

BARTELSON, Jens. What is wrong with the world?. Critical Exchange on R.B.J. Walker's After the Globe, Before the World. Contemporary Political Theory, v. 10, n. 2, 2011, p. 288-290.

BHABHA, Homi. The Location of Culture. London/New York: Routledge. 1994

BLANEY, David; INAYATULLAH, Naeem. Savage Economics: Wealth, poverty and the temporal walls of capitalism. London and New York: Routledge. 2010.

BUTLER, Judith. What is critique? An essay on Foucault's virtue. In: INGRAM, David (ed). The Political: Readings of Continental Philosophy. Oxford: Blackwell Publishers, 2002, p. 212-228.

BUZAN, Barry; LITTLE, Richard. Reconceptualizing Anarchy: Structural Realism Meets World History. European Journal of International Relations, vol. 2, n. 4, 1996, p. 403-438.

CHAKRABARTY, Dipesh. Provincializing Europe. Postcolonial Thought and Historical Difference. Princeton and Oxford: Princeton University Press. 2000.

CHATTERJEE, Partha. The Nation in Heterogeneous Time. In: CHATTERJEE, Partha. The Politics of the Governed. Reflections on Popular Politics in Most of the World. New York: Columbia University Press. 2004

CHAMON, Paulo; LAGE, Victor Coutinho. Resisting the denial of coevalness in International Relations: provincializing, perspectivism, border thinking. Revista Brasileira de Relações Internacionais, special issue: Many Worlds, Many Theories. forthcoming.

CONTEXTO INTERNACIONAL, Special Issue Towards a Global Conversation, vol. 37, n. 5, 2015.

17 See Osborne (1995, ch.1). 
DAVIS, Kathleen. Periodization and Sovereignty. How ideas of feudalism and secularization govern the politics of time. Philadelphia: University of Pennsylvania Press. 2008.

FASOLT, Constantin. The limits of history. Chicago: University of Chicago. 2004.

FOUCAULT, Michel. Politics, polemics, problematization. In: RABINOW, Paul. The Foucault Reader. New York: Pantheon books, 1984, p. 381-390.

FOUCAULT, Michel. What is critique?. In: LOTRINGER, Sylvère; HOCHROTH, Lysa (eds). The Politics of Truth. Michel Foucault. New York: Semiotext(e), 1997, p. 23-82.

FOUCAULT, Michel. .The order of things. New York and London: Routledge. 2002.

HOBSON, John. The Eurocentric conception of World Politics. Cambridge: Cambridge University Press. 2012.

HUTCHINGS, Kimberly. Happy Anniversary! Time and critique in International Relations theory. Review of International Studies, 33, 2007, p. 71-89.

HUTCHINGS, Kimberly. Time and World Politics. Thinking the present. Manchester \& New York: Manchester University Press. 2008.

INAYATULLAH, Naeem; BLANEY, David. International Relations and the Problem of Difference. London \& New York, Routledge. 2004.

JONES, Branwen (ed). Decolonizing International Relations. New York: Rowman \& Littlefield Publishers. 2006.

LINKLATER, Andrew. The Transformation of Political Community. Ethical Foundations of the Post-Westphalian Era. Cambridge: Polity Press. 1998.

LINKLATER, Andrew. Critical Theory and World Politics. Citizenship, sovereignty and humanity. London and New York: Routledge. 2007.

MUPPIDI, Himadeep. The Colonial Signs of International Relations. Oxford: Oxford University Press. 2012.

OSBORNE, Peter. Modernity is a qualitative, not a chronological, category. New Left Review, I/192, 1992, p. 65-84.

OSBORNE, Peter. The Politics of Time. Modernity and Avant-garde. London: Verso. 1995.

ONUF, Nicholas. Seven Metaphors in Search of a Good Story. In: NOGUEIRA, João Pontes; WALKER, R.B.J. (eds.). International Relations and the (Re)Invention of History. London and New York: Routledge. Forthcoming.

PHILPOTT, Daniel. Revolutions in sovereignty: how ideas shaped modern international relations. Princeton: Princeton University Press. 2001.

REUS-SMIT, Christian. The Moral Purpose of the State: Culture, Social Identity, and Institutional Rationality in International Relations. Princeton: Princeton University Press. 1999.

RUGGIE, John Gerard. Territoriality and Beyond: problematizing modernity in International Relations. International Organization, vol. 47, no. 1, 1993, p. 139-174.

SHAPIRO, Michael. National times and Other Times: Re-Thinking Citizenship. Cultural Studies, v. 14 n. 1 , 2000, p. 79-98. 
SHAPIRO, Michael. Politics and time: documenting the event. Cambridge: Polity Press. forthcoming. SHILLIAM, Robbie (ed). International Relations and Non-Western Thought. Imperialism, colonialism and investigations of global modernity. London \& New York: Routledge. 2011.

SPRUYT, Hendrik. The Sovereign State and its Competitors: an analysis of systems change. Princeton: Princeton University Press. 1994.

WALKER, R.B.J. After the Globe, Before the World. London and New York: Routledge. 2010.

WALKER, R.B.J. Inside/Outside: international relations as political theory. Cambridge: Cambridge University Press. 1993.

WALKER, R.B.J. World, Politics. Critical Exchange on R.B.J. Walker's After the Globe, Before the World. Contemporary Political Theory, v. 10, n. 2, 2011 , p. 303-310. 